\title{
THE UK'S REFERENDUMS DURING ITS INTEGRATION INTO THE EU (1973-2016)
}

\author{
Chu Thanh Van* \\ VNU University of Languages and International Studies \\ Pham Van Dong, Cau Giay, Hanoi, Vietnam \\ Received 3 May 2020 \\ Revised 16 July 2020; Accepted 15 November 2020
}

\begin{abstract}
Throughout the UK's integration into the EU (1973-2016), referendums were considered and used as an effective political tool for the Government to negotiate with the common people on important issues. During the period of 43 years, the Government called for their practices 12 times with an uneven frequency between the UK's leaders, namely the UK's Prime Ministers. One important notice is that among the 12 referendums, only two have direct links to the relationship between the UK and the EU. This article looks into the use of referendums in the UK in general and the two that are directly related to the EU in particular in the period of 1973-2016. Its conclusion and findings are expected to help outline the usage of this political tool in the contemporary and futuristic climax of the country.
\end{abstract}

Keywords: UK, EU, referendums, integration, political tool

\section{The referendums during the UK's integration into the $\mathrm{EU}$}

Referendum is defined as "the principle or practice of submitting to popular vote a measure passed on or proposed by a legislative body or by popular initiative" or "a diplomatic agent's note asking for government instructions" (Merriam-Webster, 2020).

Discussing the use of referendums in the kingdom, the UK's diplomats and elites comment: "Referendums, by which citizens are given opportunity to express a view on specific issues, have antecedents in the Middle Ages and earlier... But in comparison with some other democracies, the referendum has been little used in the United Kingdom" (House of Lords, 2010, p. 7).

During the 43 years integrating the $\mathrm{UK}^{1}$ into the $\mathrm{EU}^{2}$, referendum was used 12 times as listed in the table below, two of which are directly related to the country's presence in the EU.

\begin{tabular}{|c|c|c|c|c|c|}
\hline $\begin{array}{l}\text { Ordinal } \\
\text { number }\end{array}$ & Date/year & Issue & Scale & $\begin{array}{c}\text { UK Prime } \\
\text { Minister's regime }\end{array}$ & Result \\
\hline 1 & $\begin{array}{l}8 \text { March } \\
1973\end{array}$ & $\begin{array}{l}\text { whether Northern Ireland } \\
\text { should remain part of the } \\
\text { United Kingdom or join the } \\
\text { Republic of Ireland }\end{array}$ & $\begin{array}{l}\text { Local } \\
\text { (Northern } \\
\text { Ireland) }\end{array}$ & $\begin{array}{l}\text { Ted Heath (The } \\
\text { Conservative) }\end{array}$ & YES \\
\hline 2 & $\begin{array}{l}5 \text { June } \\
1975\end{array}$ & $\begin{array}{l}\text { whether the UK should stay } \\
\text { in the European Community }\end{array}$ & $\begin{array}{l}\text { Nation-wide } \\
\text { (the UK) }\end{array}$ & $\begin{array}{l}\text { Harold Wilson (The } \\
\text { Labour) }\end{array}$ & YES \\
\hline
\end{tabular}

\footnotetext{
* Tel.: 0983606106,

Email: chuthanhvan1979@gmail.com
}
1 The abbreviation of The European Union, a powerful regional institution of 27 countries and territories (the data updated to November, 2020) in Europe.
2 The abbreviation of The United Kingdom and Northern Ireland, a powerful country in Europe whose GDP ranks the fifth of the 196 global economies in 2019.




\begin{tabular}{|c|c|c|c|c|c|}
\hline 3 & $\begin{array}{l}1 \text { March } \\
1979\end{array}$ & $\begin{array}{l}\text { whether there should be a } \\
\text { Scottish Assembly }\end{array}$ & $\begin{array}{c}\text { Local } \\
\text { (Scotland) }\end{array}$ & $\begin{array}{l}\text { James Callaghan } \\
\text { (The Labour) }\end{array}$ & $\begin{array}{l}\text { YES but still } \\
\text { not a VALID } \\
\text { RESULT }^{1}\end{array}$ \\
\hline 4 & $\begin{array}{l}1 \text { March } \\
1979\end{array}$ & $\begin{array}{l}\text { whether there should be a } \\
\text { Welsh Assembly }\end{array}$ & $\begin{array}{l}\text { Local } \\
\text { (Wales) }\end{array}$ & $\begin{array}{l}\text { James Callaghan } \\
\text { (The Labour) }\end{array}$ & NO \\
\hline 5 & $\begin{array}{c}11 \\
\text { September } \\
1997\end{array}$ & $\begin{array}{c}\text { whether there should be } \\
\text { a Scottish Parliament } \\
\text { and whether the Scottish } \\
\text { Parliament should have tax } \\
\text { varying powers }\end{array}$ & $\begin{array}{c}\text { Local } \\
\text { (Scotland) }\end{array}$ & $\begin{array}{l}\text { Tony Blair (The } \\
\text { Labour) }\end{array}$ & YES \\
\hline 6 & $\begin{array}{c}18 \\
\text { September } \\
1997\end{array}$ & $\begin{array}{c}\text { whether there should be } \\
\text { a National Assembly for } \\
\text { Wales }\end{array}$ & $\begin{array}{l}\text { Local } \\
\text { (Wales) }\end{array}$ & $\begin{array}{l}\text { Tony Blair (The } \\
\text { Labour) }\end{array}$ & YES \\
\hline 7 & $\begin{array}{l}7 \text { May } \\
1998\end{array}$ & $\begin{array}{l}\text { whether there should be } \\
\text { a Mayor of London and } \\
\text { Greater London Authority }\end{array}$ & $\begin{array}{l}\text { London } \\
\text { - Greater } \\
\text { London }\end{array}$ & $\begin{array}{l}\text { Tony Blair (The } \\
\text { Labour) }\end{array}$ & YES \\
\hline 8 & $\begin{array}{l}22 \text { May } \\
1998\end{array}$ & $\begin{array}{l}\text { Belfast Agreement } \\
\text { referendum on the Good } \\
\text { Friday Agreement }\end{array}$ & $\begin{array}{l}\text { Northern } \\
\text { Ireland }\end{array}$ & $\begin{array}{l}\text { Tony Blair (The } \\
\text { Labour) }\end{array}$ & YES \\
\hline 9 & $\begin{array}{l}3 \text { March } \\
2011\end{array}$ & $\begin{array}{l}\text { whether the National } \\
\text { Assembly for Wales should } \\
\text { gain the power to legislate } \\
\text { on a wider range of matters }\end{array}$ & $\begin{array}{l}\text { Local } \\
\text { (Wales) }\end{array}$ & $\begin{array}{l}\text { David Cameron } \\
\text { (The Conservative) }\end{array}$ & YES \\
\hline 10 & 5 May 2011 & $\begin{array}{l}\text { whether to change the } \\
\text { voting system for electing } \\
\text { MPs to the House of } \\
\text { Commons from first past the } \\
\text { post to the alternative vote }\end{array}$ & $\begin{array}{l}\text { Nation-wide } \\
\text { (the UK) }\end{array}$ & $\begin{array}{l}\text { David Cameron } \\
\text { (The Conservative) }\end{array}$ & $\mathrm{NO}$ \\
\hline 11 & $\begin{array}{c}18 \\
\text { September } \\
2014\end{array}$ & $\begin{array}{l}\text { whether Scotland should } \\
\text { become an independent } \\
\text { country }\end{array}$ & $\begin{array}{c}\text { Local } \\
\text { (Scotland) }\end{array}$ & $\begin{array}{l}\text { David Cameron } \\
\text { (The Conservative) }\end{array}$ & NO \\
\hline 12 & $\begin{array}{l}23 \text { June } \\
2016\end{array}$ & $\begin{array}{l}\text { whether the UK should } \\
\text { remain in the EU }\end{array}$ & $\begin{array}{l}\text { Nation-wide } \\
\text { (the UK) }\end{array}$ & $\begin{array}{l}\text { David Cameron } \\
\text { (The Conservative) }\end{array}$ & NO \\
\hline
\end{tabular}

Tracing back to the origin of referendums in the UK's history, many authors agree that this tool has been created as a prominent example or illustration of the democracy (Atkinson \& Blick, 2017). The court by Arthur King in the $11^{\text {th }}$ century was well-known all over Europe as the most brilliantly democratic political system compared to those of the neighboring countries meanwhile (Staropoli, 2014). This country has been prestigiously famous as the land of democracy since then. Later, in the $17^{\text {th }}$ century, the UK was also recognized as the cradle of the parliamentary governmental institution (history. com, 2019). The peaceful cohabitation between the monarchy institution and the parliamentary institution in Britain over the time has been considered a symbol of highest democracy, where different political theorems and systems can live in harmony with each other. In the modern time, the use of referendums in this country once more proves the widespread democracy here - towards and inside each of its citizens, offering them a chance to raise their voice and participate in the nation's duties and welfare.

Generally the referendums used in the UK are aimed at the following targets:

\footnotetext{
1 The regulations on valid results of a referendum requires at least 40 per cent of the electorate to vote yes, but here in this referendum a small majority, which was short of 40 per cent threshold, voted yes and made the result invalid. Therefore, after the referendum, the devolution was still not enacted.
} 
(1) enhancing the democratic process; (2) being a "weapon of entrenchment"; (3) settling an issue; (4) being a "protective device"; (5) enhancing citizen engagement; (6) promoting voter education; (7) ensuring that voters are able to make sound judgments; (8) being popular with voters; (9) complementing representative democracy (House of Lords, 2010, pp. 13-16).

However, many politicians have pointed out the weaknesses of this political tool which are indiscernibly true to the nature of British context. The most widely approved drawbacks include: (1) referendums are just a tactical device; (2) they are dominated by elite groups; (3) they can have a damaging effect on minority groups; (4) referendums are a "conservative" device; (5) they do not effectively "settle" an issue; (6) they fail to deal with complex issues; (7) they tend not to be about the issue in question; (8) voters show little desire to participate in referendums; (9) they are costly; (10) referendums undermine representative democracy (House of Lords, 2010, pp. 16-20).

Due to the fact that the number of advantages of referendums does not completely outweigh the disadvantages, its usage can trigger serious controversy among related parties and individuals.

\section{An analysis of the referendums during the UK's integration into the EU}

In-depth investigation into the Table of Referendums in the UK during 1973-2016 has revealed important findings and indications on the health of the country's politics, as well as its relationship with the EU.

On the issue of domestic politics, the table shows that of the twelve referendums carried out in the UK in the period of 1973-2016, there are only three at the nation-wide level.
Furthermore, of the nine local ones, three took place in Scotland, three in Wales, two in Northern Ireland and only one referendum in the territory of London-Greater London. These practices indicate the conflicts that run quietly among the four components of the nation, namely Scotland, Wales, England and Northern Ireland. England with its capital city of London and most of the country's headquarters of the political, cultural and economic life seems to maintain the most concrete stability for the territory during the given time. The situation also reflects a fact that the local authorities in the UK are dynamic and are asking for continuous devolution from the central government.

On the matter of leadership styles or leader charisma, Margaret Thatcher seems to be the most dominant. During her time in the office, there was no single referendum held in the UK, either at the local or national level. This situation may partly be attributed to the party division and domestic and international political stability, too. The most chaotic period presented in David Cameron's government. Five years of his time witnessed four referendums, three of them came out with his dissatisfaction (three NO - results). While his peer in the Conservative, Margaret Thatcher was disinterested at the EU summit meetings because of her straightforward and dominant manners (Pilkington, 2001), Cameron maintained a more reasonable voice to ensure his respect and position at Brussels, which is also his weakness when the UK's problematic politics asked him to be more attached to the country's sovereignty and benefits (Chu Thanh Van, 2017, pp. 92-138). The ironic aspect of the last referendum on the position of the UK in the EU is that while the nation had assigned its government to deal with all negotiations with the EU on conditions for its further staying in the Union, it required the final 
decision of leaving or remaining to be made by the common people, who had much less information and truths on what was genuinely going in the Union and who had been easily hijacked or kidnapped by the populists - those have ingrained inside the country so deeply that they understand clearly every pros and cons of the British nature. This fact has been criticized by scholars both inside and outside the country (Qvortrup, 2016; Saunders, 2016).

The four referendums carried out during Tony Blair's office time all brought out a YES answer. Tony, in fact, did actually the best of all the UK's Prime Ministers of the period 19732016. He balanced skillfully the role of mediate between the UK and the EU, leading the country into the heart of the Union as he ever promised (Berlaymon, 2007). Tony's harmonious and pleasant leadership lifestyle and the UK's gradual economic stability during his office time have been considered the two main reasons for this warm relationship (Chu Thanh Van, 2017).

On the international level, the two referendums that are directly related to the integration of the UK into the EU took place in 1975 and 2016 - a gap of 41 years when the two partners had grown up into different perspectives and positions. The 1973 referendum ensured the UK's attitudes and commitments into the EU while the 2016 opened wide the gate for the nation to exit from the Union. Together with the popularism and Euro-scepticism waken up in the continent, the Brexit in 2016 had created land-slide effects on the shaking and breaking down of regionalism and globalization not only in Europe but the whole world (Chu, 2018).

\section{The UK's 1973 and 2016 referendums during the integration into the EU: a comparison and contrast}

Most referendums are used as a tool to stabilize the domestic problems to make sure and sweep way for the whole nation entering into the EU. However, the two directly related to this regional institution bear different aspects and characteristics: the first strengthening the UK's commitments into the EU but the second opening the gate for a complete Brexit.

The 1975 referendum was carried out two years after its short-of-breath running into the European Economic Community former version of European Community or European Union. The reason was partly "After joining the Bloc in 1973, many Britons felt their island nation - a former imperial power with strong ties to the United States - was fundamentally different from its European neighbours." (Acharya, 2016). Gallup polls at that time immediately revealed a two-toone proportion of the nation's population believing that "the country had been wrong to join" (Acharya, 2016). However, the question of the referendum of whether the UK should remain in the EEC was still answered YES by the majority.

The situation in 1975 seems to be critically different from that in 2016. In the former, immigration did not come to the surface of the political chessboard as a serious problem. Instead, the country witnessed its 41,000 people leaving their homeland, due to the economic stagnation in the UK (McDowall, 1992). On the contrary, the EEC meanwhile did make triumphant progress, gradually gaining its economic power and political respects in the world arena after the Second World War (Acharya, 2016).

Under the light of domestic politics, the competition among various parties in the UK in 1975 was far less fierce than in 2016. The UKIP (United Kingdom of Independent Party) had not come into existence. The newlyelected leader of the Conservative was then 
Margaret Thatcher, who was more eager to push up the economic growth in the UK than anybody else, so she would ignore the conflicts and rivalry against the Labour Government to fight for just the prosperity of the whole nation for a while. The populist movement was still sleepy and the influence of the media had not been supported tremendously with the worldwide web and the Internet.

Outside in the region, the EEC did not reveal its ambitious plan of uniting the Europeans all together in the three most important "pillars" of economy (in the European Communities), common foreign and security policy (CFSP) and cooperation in the field of justice and home affairs (JHI) (Europarl, 2020). The worries on loss of sovereignty did not come to the mind of the member country leaders yet as there seems to be nothing related to power and politics to concern. The economic crisis starting in 2008 had shaded gloomy prospects for most Eurozone countries and the EU was continuously urging the stable wealthy Britain to support the other desperate members. The immigrants rushing to the EU from Africa and poor Asian parts and the imposed quotas that asked the UK to receive them from Brussels had created fire among the Britons famous for being cold, calculating, and conservative.

In short, the scenarios domestically and internationally of the two referendums are completely different. In 1973, the poor miserable Britain was pledging the wealthy EEC for a permission into this institution, accepting to pay a higher price in the form of financial contributions than the other members for an opportunity to prosperity. In the 2016, a calculating Britain was witnessed to try to avoid the further the better the EU and its problems of weakening economies, immigration crisis and chaotic political mess of uprising popularism. Besides, the UK's reluctance during its integration into the EU, its burden of financial support for this regional institution, the Eurozone crisis, and the UK's weakening effects on the EU compared to those by the French and the German etc. have all contributed to the emergence of the 2016 historic referendum in the UK. This referendum has been created not only from the "inside" any more. The outside factors and historic relationship of the UK-EU has been significantly attributed (Chu Thanh Van, 2017).

\section{The prospect of using the referendum in the UK's political context}

At the present time of 2020, the UK has been led by a new Conservative Prime Minister, Boris Johnson to fulfill its wish of exiting from the EU. All the arrangements and negotiations have been made and the Brexit is certain to come true after numerous cancellations or reluctances. The question is whether referendum has any chance of being exploited in the UK's contemporary context.

After so many heated conflicts and arguments on the use of the referendum in 2016 and the chaotic mess it has created, it is high time for different political parties to get together to try to reconcile the hostile atmosphere. The fact that the 2016 referendum has been severely criticized as it had given the common people too much power and a big mouth on the nation's vital foreign policy without concrete wisdom and knowledge on the issue has forced all related parties and individuals to slow down the pushing up of their ambitions and self-expressions or selfesteem. Domestic political contradictions are going to be brought down to a stable, easily-controlled level. Boris Johnson has proven to be the next dominant leader of the 
Conservative with certain firm decisions on domestic matters and international negotiations like the ones he did when discussing final conditions for the Brexit with the EU officials recently (Partington, 2020; Ellyatt, 2020). Therefore, the use of referendums in the near future, at least within Boris Johnson's office time, is going to be painstakingly calculated with more scrutiny.

Outside on the world arena and regional level, international pressures on the UK's politics are promised to be lessened when approximately all the countries on Earth are busy dealing with their domestic matters and the fighting against the Covid-19, or SarsCoV-2 pandemic in the first half of the 2020. Also the war trade between China and the USA has not come to an end yet; and therefore most other countries, with the UK included, will wish to stand by to watch for coming signals before switching or steering to more fertile actions. The pressure, if there is any, on the use of referendums in the UK from the outside world is expected to go down or even disappear for the short term.

In short, considering all the pros and cons of the referendum, and taking into account the present Prime Minister Boris Johnson's leadership, the nation's contemporary political context as well as its relationship with other countries in the region and the world, it is possible to come to conclude that referendums in the UK will not be of much use within 3-5 years from now, especially the ones associated with significant foreign policies such as the relationship of the UK with a great power and regional cooperator - the EU.

\section{Conclusions}

The use of any political tool has always hidden both pros and cons. The referendum is at no time an exception. During 43 years entering and integrating into the $\mathrm{EU}$, the UK did carry out 12 referendums, most of which aimed at reconciling or facilitating its domestic political institutionalizations, making way for further influences outwards later. The two referendums closely associated with the EU keep different roles: the first to confirm the UK's commitment and determination into the Union whilst the second unlocking the door for the country to exit from it. Generally speaking, the use of referendum and its usefulness are up to a great number of factors, some of which are the leader's abilities, the government's capacities, domestic and international contexts, and characteristics, knowledge and thinking of the nation's people. In the very near future of at least this office term by the present UK's Conservative Prime Minister Boris Johnson, the practice of referendum as a political tool is expected to continue its use whenever there is any domestic controversy concerned. Outside in Europe, as the link between the UK and the EU has been cut off with the Brexit, the possibility for referendums related to this relationship being called for has become limited in the short term.

\section{Reference}

\section{Vietnamese}

Chu Thanh Vân (2017). Chính sách của Anh đối với $E U$ tù 1992 đến 2016. Luận án Tiến sĩ, Trường Đại học Khoa học Xã hội và Nhân văn, Đại học Quốc gia Hà Nội.

\section{English}

Acharya, D. (2016, June 25). Brexit in 2016 and 1975: Two historical EU referendums speak of two different ideas of Britain. Firstpost. Retrieved from https://www.firstpost.com/world/brexit-in-2016and-1975-two-historical-eu-referendums-speak-oftwo-different-ideas-of-britain-2853954.html

Atkinson, L., \& Blick, A. (2017). Referendums and the Constitution. Retrieved from https://consoc. org.uk/wp-content/uploads/2017/02/Web-versionReferendums-paper.pdf 
Berlaymon, S. (2007, May 30). Tony Blair and Europe. Retrieved from https://www.opendemocracy.net/en/ tony_blair_and_europejsp/

Chu, T. V. (2018). Britain's Policies towards the EU: Integration or Foreign Policy Theories? VNU Journal of Foreign Studies, 34(5), 172-179.

Ellyatt, H. (2020, January 21). How Boris Johnson could 'put down a firm line' in EU trade talks. CNBC. Retrieved May 3, 2020, from https://www.cnbc. com/2020/01/21/boris-johnson-could-put-down-afirm-line-in-eu-talks-chatham-house.html

Europarl (2020). The Maastricht and Amsterdam Treaties. Retrieved from https:/www.europarl. europa.eu/ftu/pdf/en/FTU_1.1.3.pdf

History.com editors (2019). British Parliament. Retrieved July 11, 2020, from https://www.history. com/topics/british-history/british-parliament

House of Lords (2010). Referendums in the United Kingdom. Retrieved from https://publications. parliament.uk/pa/ld200910/ldselect/ldconst/99/99.pdf

McDowall, D. (1992). Britain in Close-up. Ho Chi Minh City: Tre Publishing House.
Partington, R. (2020, February 3). Pound falls as Boris Johnson takes tough line on EU trade deal. The Guardian. Retrieved from https://www.theguardian. com/business/2020/feb/03/pound-falls-as-borisjohnson-takes-tough-line-on-eu-trade-deal-brexit

Pilkington, C. (2001). Britain in the European Today (2nd ed.). Manchester : Manchester University Press.

Qvortrup, M. (2016, June 21). Europe Has a Referendum Addiction. FP. Retrieved from https://foreignpolicy. com/2016/06/21/europes-referendum-mania-brexit/

Referendum. (n.d.). In Merriam-Webster. Retrieved from https://www.merriam-webster.com/dictionary/ referendum

Saunders, R. (2019, October 24). Britain decides: the first European referendum. HistrotyExtra. Retrieved from https://www.historyextra.com/period/modern/ britain-decides-the-first-european-referendum/

Staropoli, K. D. (2014). The Evolution of The Legend of King Arthur. Retrieved from https://surface.syr.edu/cgi/viewcontent. cgi? article $=1747 \&$ context $=$ honors_capstone

\title{
NHŨ'NG CUỘC TRƯNG CẦU DÂN Ý CỦA NƯỚC ANH TRONG THỜI KỲ HỘI NHẬP EU (1973-2016)
}

\author{
Chu Thanh Vân \\ Khoa Tiếng Anh, Trường Đại học Ngoại ngũu - Đại học Quốc gia Hà Nội \\ Phạm Văn Đồng, Cầu Giấy, Hà Nội, Việt Nam
}

Tóm tắt: Trong thời kỳ nước Anh hội nhập vào EU (1973-2016), các cuộc trưng cầu dân ý của nước này đã được sử dụng và được xem là công cụ chính trị hữu ích giúp Chính phủ đàm phán với người dân trong các vấn đề quan trọng. Suốt giai đoạn 43 năm hội nhập vào tổ chức khu vực lớn này, Chính phủ Anh đã thực hiện trưng cầu dân ý 12 lần, với tần suất không đều nếu so sánh theo các đời lãnh đạo Chính phủ (tức Thủ tướng). Một điểm nổi bật quan trọng nữa là trong số 12 cuộc trưng cầu dân ý kể trên, chỉ có hai cuộc trưng cầu liên quan trực tiếp đến mối quan hệ giữa Anh và EU. Bài báo này nghiên cứu 12 cuộc trưng cầu dân ý đã được thực hiện trong lãnh thổ nước Anh nói chung và hai cuộc trưng cầu dân ý liên quan trực tiếp đến EU nói riêng thuộc giai đoạn 1973-2016. Kết luận và kết quả của nghiên cứu được xem là có thể giúp vạch ra lộ trình sử dụng loại hình công cụ chính trị này ở nước Anh trong bối cảnh chính trị hiện tại và trong tương lai.

Tù khóa: UK, EU, trưng cầu dân ý, hội nhập, công cụ chính trị. 